\title{
Bercocok Tanam Dengan Sistem Hidroponik Berbasis Ramah Lingkungan Melalui Pemanfaatan Sampah Botol Plastik
}

\author{
Planting with Environment-Based Hydroponic Systems Using Plastic Bottle \\ Fitri Damayanti dan Titin Supriyatin \\ Program Studi Pendidikan Biologi FMIPA Universitas Indraprasta PGRI Jakarta \\ Email: fitridamayantineng@gmail.com
}

\begin{abstract}
ABSTRAK
Sampah plastik termasuk botol plastik adalah jenis sampah yang sangat sulit terurai sehingga menimbulkan masalah kebersihan dan kesehatan lingkungan. Secara umum masyarakat belum memiliki kemampuan dalam mengolah sampah botol plastik sehingga terjadi penumpukan. Sampah botol plastik tersebut belum termanfaatkan menjadi sesuatu yang berguna. Permasalahan lain yang dihadapi mitra adalah terbatasnya lahan dan waktu yang dimiliki mitra untuk bercocok tanam. Solusi yang ditawarkan adalah penerapan teknik bercocok tanam dengan sistem hidroponik berbasis ramah lingkungan dengan memanfaatkan sampah botol plastik. Kegiatan dilakukan dengan mentransfer pengetahuan kepada mitra melalui pelatihan pembuatan perangkat sistem hidroponik sederhana menggunakan botol plastik sebagai media tanam sayuran. Kegiatan pengabdian kepada masyarakat dilakukan dengan mitra PKK Karang Anyar, Kecamatan Sawah Besar, Jakarta Pusat. Kegiatan ini bertujuan memperkenalkan cara bercocok tanam dengan sistem hidroponik berbasis ramah lingkungan melalui pemanfaatan daur ulang botol plastik. Kegiatan ini merupakan salah satu terobosan dalam mengurangi masalah plastik dengan menciptakan lingkungan yang bersih, hijau, dan asri. Setelah pelatihan terjadi peningkatan pengetahuan mitra mengenai pemanfaatan sampah botol plastik dan terbukti juga berhasil meningkatkan minat peserta untuk memanfaatkan botol plastik bekas untuk bercocok tanam di rumah. Mitra memberikan respon yang sangat positif terhadap kegiatan yang telah dilakukan dan menilai kegiatan ini sangat bermanfaat. Selain itu, kegiatan ini dapat mendorong kemandirian ekonomi mitra dengan mengurangi biaya belanja rumah tangga sehari-hari terutama sayuran.
\end{abstract}

Kata kunci: botol plastik, daur ulang, hidroponik

\begin{abstract}
Plastic waste as well as plastic bottles is a type of waste that are very difficult to decompose. That has caused environmental and hygiene problems. In general, the community does not yet have the ability to process plastic bottle waste that cause buildup. Plastic bottle waste has not been much used as something useful. Others problems that has againt partner are limited land and time to grow crops. The solution offered was the application of agricultural techniques using environmentally friendly hydroponic systems based on plastic bottle waste. This activity was carried out by transferring knowledge to partner through training in making a simple hydroponic system using plastic bottles as a medium for growing vegetables. Community service activities were carried out with PKK Karang Anyar, Sawah Besar Regency, Jakarta as a partner. This activity aimed to introduce how to plant with an environmentally friendly hydroponic system based on the use of recycled plastic bottles. This activity is one of the breakthroughs in reducing plastic
\end{abstract}

http://ejournal.urindo.ac.id/index.php/PAMAS

Article History :

Submitted 24 Januari 2020, Accepted 26 April 2020, Published 29 April 2020 
problems by creating a clean, green, and beautiful environment. After the training there was an increase in partner's knowledge about the use of plastic bottle holders and it was proven that it also succeeded in increasing participants' interest in using plastic bottles for farming at home. Partner gave very positive response to the activities that have been carried out and feel this activity was very beneficial. In addition, this activity could encourage the economic independence of partners by reducing the cost of daily household expenses, especially vegetables.

Keywords: plastic bottle, recycle, hydroponic

\section{LATAR BELAKANG}

Sampah plastik merupakan salah satu permasalahan serius di Indonesia terutama untuk daerah perkotaan. Berdasarkan data KLHK (2018), sampah plastik menempati urutan kedua terbanyak dari seluruh jenis sampah yaitu mencapai $12.4 \%$. Plastik banyak digunakan dalam kehidupan manusia karena sifat plastik yang ringan, murah, dan praktis sehingga dapat menggantikan kegunaan barang dari bahan lain. Oleh karena itu plastik lebih banyak dipakai sebagai barang sekali pakai. Hal ini menyebabkan semakin tingginya penggunaan perlengkapan dari bahan plastik terutama kemasan air minum yang didominasi oleh botol plastik.

Umumnya masyarakat membuang sampah botol plastik di tempat-tempat umum seperti di sungai, jalan, atau halaman kosong. Pembuangan sampah botol plastik yang tidak terkendali dan tidak pada tempatnya menjadi suatu masalah yang sangat mengkhawatirkan. Masyarakat secara umum belum mampu mengolah sampah dengan baik akibatnya terjadi penumpukan sampah botol plastik. Sampah plastik sangat sulit terurai sehingga menimbulkan masalah kebersihan dan kesehatan lingkungan. Selain itu, masalah banjir menjadi ancaman utama akibat pembuangan sampah yang sembarangan.

Salah satu upaya mengelola sampah botol plastik adalah melakukan gerakan recycle (daur ulang) atau gerakan recreate sehingga memiliki nilai ekonomis. Gerakan ini sangat berguna bagi lingkungan atau untuk mendapat barang baru. Oleh karena itu perlu adanya upaya perancangan pemanfaatan sampah botol plastik yang benar sehingga menjadikan suatu yang bermanfaat dan bernilai ekonomi.

Berdasarkan pantauan dan hasil diskusi dengan mitra yaitu kelompok PKK Karang Anyar yang berlokasi dekat dengan RPTRA Karang Anyar, Kecamatan Sawah Besar, permasalahan yang dihadapi adalah tumpukan sampah botol plastik. Sampah botol plastik ini berasal dari para pengunjung yang memanfaatkan sarana dan prasarana di RPTRA Karang Anyar. Tumpukan sampah botol plastik tersebut belum termanfaatkannya menjadi sesuatu yang berguna dan menjadi barang yang bermanfaat. Hal ini karena kurangnya 
pengetahuan masyakarat sekitar dalam memanfaatkan sampah botol plastik secara maksimal hingga memiliki nilai ekonomi. Salah satu solusi untuk mengatasinya adalah dengan melakukan upaya daur ulang sampah, sehingga diharapkan volume sampah plastik bisa berkurang. Permasalahan lain yang dihadapi mitra adalah terbatasnya lahan dan waktu yang dimiliki mitra untuk bercocok tanam. Keterbatasan lahan dapat diatasi dengan penerapan bercocok tanam sistem hidroponik. Namun penerapan metode ini membutuhkan biaya yang tergolong mahal terkait dengan perangkat hidroponik.

Alternatif solusi yang ditawarkan untuk mengatasi permasalahan-permasalahan mitra adalah penerapan gerakan recreate sampah botol plastik menjadi bernilai ekonomi. Gerakan recreat yang diterapkan adalah pemanfaatan sampah botol plastik untuk wadah bercocok tanam sayuran dengan metode hidroponik dalam bentuk penyuluhan dan pelatihan pembuatan perangkat sistem hidroponik sederhana menggunakan botol plastik sebagai media tanam sayuran.

Budidaya tanaman sayuran secara hidroponik dengan memanfaatkan botol plastik mampu membangkitkan tumbuhnya mata rantai usaha melalui penciptaan pemanfaatan sampah botol plastik dan peningkatan kesejahteraan dan kesehatan masyarakat. Hal ini dikaitkan dengan upaya pemerintah untuk meningkatkan kesehatan masyarakat melalui kesadaran mengkonsumsi sayuran.

Bercocok tanam secara hidroponik telah berhasil diterapkan pada beberapa jenis sayuran, antara lain pada tanaman bayam (Wachjar dan Anggayuhlin, 2013), komatsuna (Azad et al., 2013), pakchoi (Wibowo dan Asriyanti, 2013; Sesanti dan Sismanto, 2014; Sutinah, 2016;), kailan dan sawi (Pratiwi dkk., 2015). Penerapan teknik hidroponik juga telah diaplikasikan pada tanaman hias seperti pada bunga lili (Asker, 2015). Budidaya sayuran dengan sistem ini mampu meningkatkan pertumbuhan produktivitas sayuran hingga dua kali dari penanaman secara konvensional (Sardare and Admane, 2013; Roidah, 2014; Barbosa et al., 2015; Romadloni, 2015; Jenskin et al., 2015; Mohammed and Sookoo, 2016). Selain itu penerapan hidroponik juga menghasilkan tanaman yang bebas zat berbahaya seperti garam (Rababah, 2017) atau logam berat seperti kadmium (Babu et al., 2014).

Solusi yang diterapkan diharapkan mampu mengurangi bertumpuknya sampah botol plastik dan meningkatkan keinginan masyarakat untuk bercocok tanam. Sistem hidroponik lebih efisien diterapkan karena tidak memerlukan waktu yang lama dan lahan yang luas (Lingga, 2011). Mahalnya perangkat hidroponik dapat diatasi dengan mendaur ulang sampah botol plastik menjadi wadah untuk hidroponik. Melalui pelatihan ini 
diharapkan setiap rumah tangga dapat bercocok tanam sayuran secara hidroponik. Hasil bercocok tanam dapat digunakan untuk memenuhi kebutuhan sayuran secara mandiri tanpa harus membeli sehingga dapat mengurangi pengeluaran belanja rumah tangga. Selain itu juga dapat menciptakan lingkungan yang bersih dan sehat bebas sampah.

Kontribusi yang diharapkan dari kegiatan pengabdian kepada masyarakat ini adalah meningkatkan nilai ekonomi dari tumpukan sampah botol plastik. Kegiatan ini juga diharapkan dapat membantu warga mengatasi penumpukan sampah botol plastik dan meningkatkan daya minat bercocok tanam sayuran yang ramah lingkungan, murah dan mudah. Selain itu kebutuhan akan sayuran dapat dipenuhi secara mandiri dan menghemat pengeluaran belanja rumah tangga. Oleh karena itu kegiatan pengabdian kepada masyarakat ini diharapkan mampu meningkatkan kesehatan, kesejahteraan rumah tangga dengan menciptakan lingkungan yang asri, bersih dan sehat.

\section{METODE PELAKSANAAN}

Pelaksanaan pengabdian kepada masyarakat dilakukan dengan mitra kelompok PKK Karang Anyar RT 014/RW 001 Kelurahan Karang Anyar, Kecamatan Sawah Besar, Jakarta Pusat. Tempat kegiatan di RPTRA Karang Anyar, Kecamatan Sawah Besar, Jakarta Pusat. Kegiatan ini telah dilaksanakan pada bulan September-Desember 2019. Kegiatan ini terdiri dari beberapa tahapan, yaitu: survei dan analisis lapangan, penyuluhan, pelatihan, panen, dan evaluasi.

Survei dan analisis lapangan dilakukan agar pelaksanaan pengabdian ini dapat berjalan sesuai dengan rencana dan lancar. Kegiatan ini dilakukan di mitra dengan cara mengumpulkan mitra untuk menentukan kebutuhan yang tepat. Luaran dari tahapan ini adalah data kebutuhan jumlah peserta, waktu pelatihan dan durasi pelaksanaan pelatihan.

Penyuluhan dilakukan melalui kegiatan transfer pengetahun. Pengetahuan yang disampaikan meliputi: bahaya limbah plastik terhadap lingkungan, sistem bercocok tanam hidroponik, dan pemanfaatan sampah botol plastik untuk berbagai macam keperluan.

Pelatihan dilaksanakan setelah disetujui waktu dan tempat pelatihan. Kegiatan ini terdiri dari tiga tahapan, yaitu: pembuatan kontruksi wadah hidroponik, persemaian tanaman, dan pemindahan tanaman ke sistem hidroponik botol plastik.

a. Pembuatan konstruksi wadah hidroponik dari botol platik. Kegiatan ini diawali dengan persiapan pengumpulan sampah botol plastik. Botol-botol plastik tersebut dicuci dan ditiriskan. Botol plastik dipotong menjadi dua bagian, bagian bawah sebagai wadah 


\section{Jurnal Pelayanan dan Pengabdian Masyarakat (PAMAS)}

cairan pupuk hidroponik dan wadah atas sebagai tempat tanaman. Antara wadah atas dan bawah dihubungkan dengan kain flannel.

b. Persemaian tanaman. Tanaman sayuran yang akan ditanam adalah selada. Persemaian dilakukan menggunakan rockwool. Tempat persemaian disiapkan berupa wadah plastik atau nampan. Rockwool dibasahi dan dilubangi untuk tempat benih selada. Kemudian wadah plastik tempat persemaian ditutup dengan kain hitam selama 24 jam sampai pecah benih.

c. Pemindahan tanaman ke sistem hidroponik botol plastik. Bibit yang telah keluar 2-3 daun dipindahkan ke wadah plastik yang telah disiapkan dan berisi nutrisi hidroponik. Nutrisi hidroponik menggunakan pupuk mix A dan B yang dilarutkan dalam 1liter air.

Panen dilakukan setelah 21-28 hari. Selada disortir untuk memilih tanaman yang layak untuk dikonsumsi. Seleksi dilakukan dengan membuang daun tua, kuning, berlubang, dan robek. Daun yang disisakan pada tanaman sekitar 3-6 pucuk daun teratas.

Setelah pelaksanaan selesai, maka dilakukan evaluasi dengan mitra untuk menilai ketepatan sasaran pelatihan dan pelaksanaan pengabdian secara keseluruhan. Pencapaian kesesuaian target dilakukan melalui pengisian kuisioner untuk mengetahui tingkat pengetahuan mitra sebelum dan setelah pelatihan.

\section{HASIL DAN PEMBAHASAN}

Target capaian kegiatan pengabdian kepada masyarakat adalah untuk meningkatkan kemampuan ibu-ibu PKK mengenai bercocok tanam dengan sistem hidroponik berbasis ramah lingkungan melalui pemanfaatan sampah botol plastik.

Mitra kegiatan ini terdiri dari 20 orang yang tergabung dalam kelompok PKK Karang Anyar RT 014/RW 001 Kelurahan Karang Anyar, Sawah Besar, Jakarta Pusat. Kegiatan penyuluhan dilakukan untuk menyampaikan informasi yang meliputi: bahaya limbah plastik terhadap lingkungan, sistem bercocok tanam hidroponik, dan pemanfaatan sampah botol plastik untuk berbagai macam keperluan. Penyampaian informasi ini penting diketahui oleh mitra untuk mengatasi permasalahan sampah botol plastik di lingkungan tempat tinggal mitra. Penyuluhan ini diharapkan menambah pengetahuan mitra mengenai bahaya sampah plastik dan pemanfaatan sampah botol plastik untuk media tanam hidroponik.

Kegiatan pelatihan diikuti oleh 20 peserta. Pelatihan diberikan dalam bentuk demonstrasi dan praktek (Gambar 1). Pelatihan diikuti oleh ibu rumah tangga dengan latar belakang pendidikan akhir tingkat SMP dan SMA atau sederajat (Gambar 2). Kegiatan ini 
diharapkan mampu mendorong kemandirian ekonomi masyarakat melalui pemanfaatan sampah botol plastik. Berdasarkan target capaian kegiatan maka metode yang diterapkan untuk penyelesaian permasalahan mitra adalah melalui penyuluhan dan pelatihan.
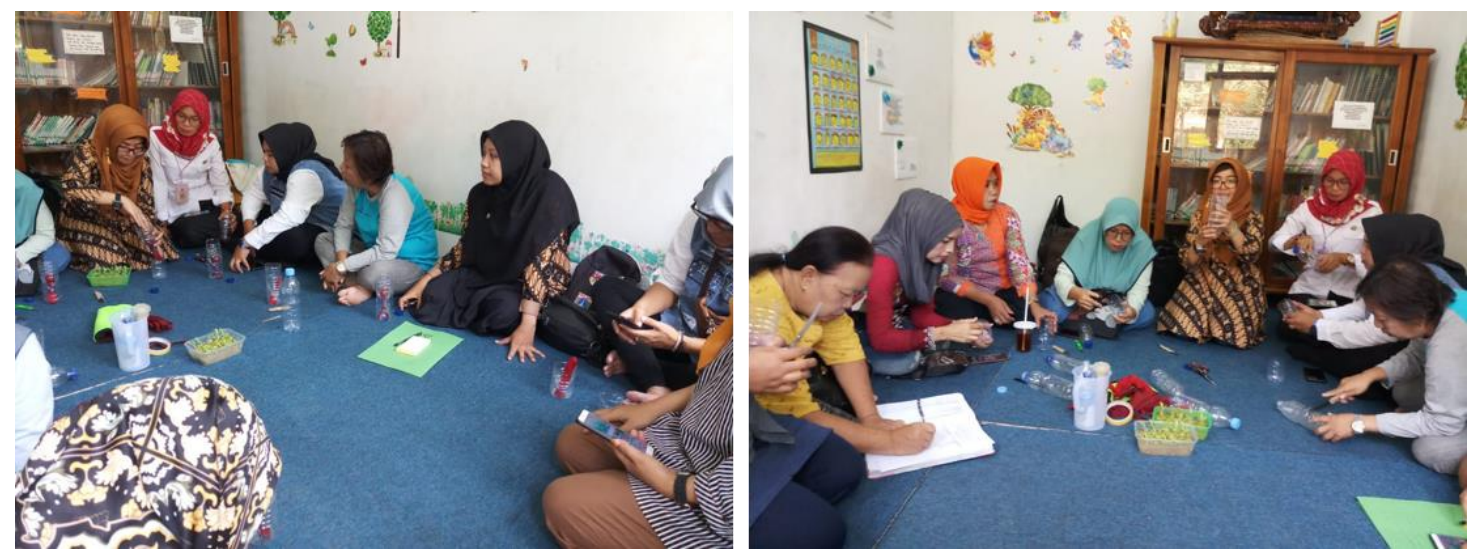

Gambar 1. Suasana pelatihan bercocok tanam sistem hidroponik dengan pemanfaatan botol plastik bekas

Pelatihan diberikan melalui metode demonstrasi yang terbagi dua, yaitu pelatihan pembibitan benih selada dan pembuatan sistem hidroponik dengan menggunakan botol plastik (Gambar 3). Botol plastik dapat dimanfaatkan untuk bercocok tanam hidroponik yang murah, mudah dan sekaligus dapat mengurangi masalah limbah botol plastik. Hasil pelatihan ini diharapkan mampu mengembangkan daya kemandirian ekonomi mitra dengan menyediakan sayur secara mandiri pada tingkat rumah tangga dengan metode hidroponik yang berbasis ramah lingkungan melalui pemanfaatan sampah botol plastik.

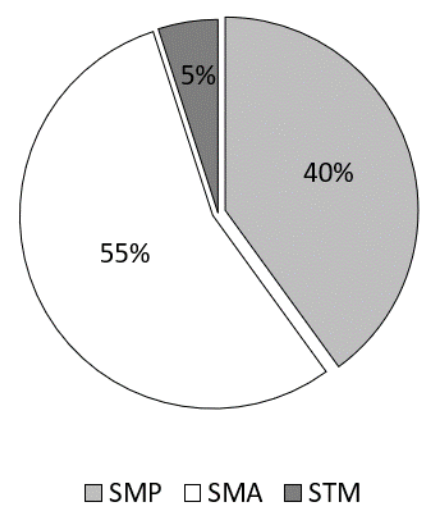

Gambar 2. Tingkat pendidikan ibu-ibu PKK Karang Anyar RT 014/RW 001 Kelurahan Karang Anyar sebagai mitra kegiatan pengabdian kepada masyarakat 


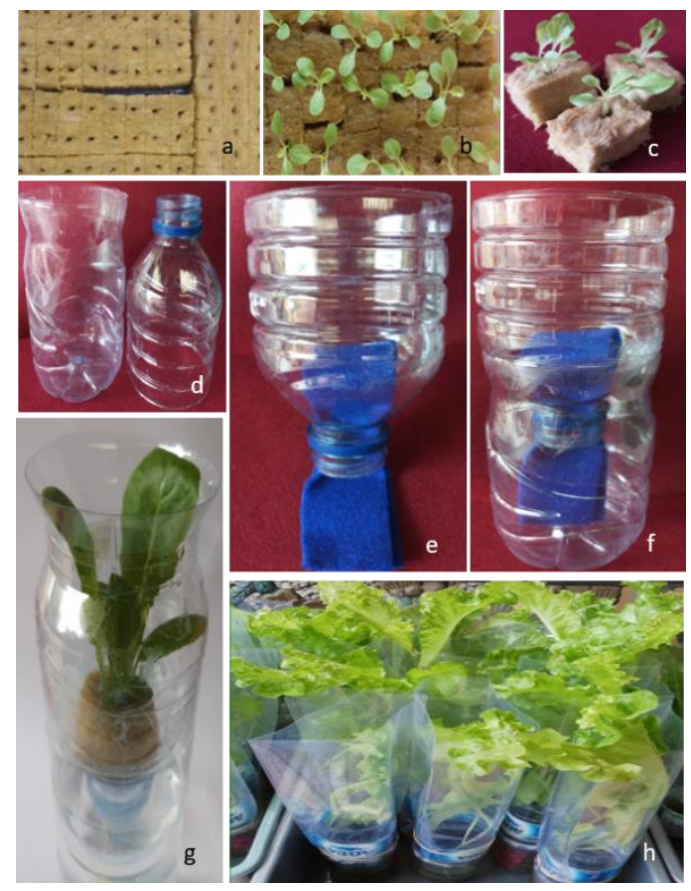

Gambar 3. Pembibitan biji selada dan pembuatan sistem hidroponik dengan menggunakan botol plastik. a-c. Persemaian tanaman. d-f. Pembuatan konstruksi wadah hidroponik dari botol platik. g. Selada dalam sistem hidroponik wadah botol plastik yang berisi nutrisi hidroponik; h. Selada siap panen setelah 21-28 hari

Peserta penyuluhan dan pelatihan menunjukkan antusias yang cukup tinggi terlihat dari respon positif yang diberikan para peserta. Respon positif tersebut terlihat dari aktifnya para peserta memberikan tanggapan dan pertanyaan yang berhubungan dengan materi penyuluhan dan pelatihan yang diberikan. Peserta juga berperan aktif dalam kegiatan praktek pembenihan biji selada dan membuat perangkat sederhana hidroponik dari sampah botol plastik. Seluruh kegiatan berjalan sesuai dengan agenda yang telah dibuat dan berjalan dengan lancar dan disiplin.

Target capaian kegiatan diukur berdasarkan hasil pengisian kuisioner oleh seluruh peserta. Kuisioner dilakukan dengan tujuan untuk mengetahui pemahaman pengetahuan yang diberikan melalui penyuluhan dan praktek bercocok tanam dengan sistem hidroponik dengan pemanfaatan sampah botol plastik. Kuisioner berisi beberapa pertanyaan yang berhubungan dengan pengetahuan peserta mengenai pemanfaatan sampah botol plastik, bercocok tanam dengan sistem hidroponik, dan pemanfaatan botol bekas untuk media bercocok tanam hidroponik. Jawaban peserta dalam bentuk pilihan. Terdapat dua kategori pilihan jawaban, yaitu kelompok pilihan jawaban: ya dan tidak serta kelompok pilihan jawaban: setuju, ragu-ragu, dan tidak setuju. 
Pengetahuan peserta pemanfaatan daur ulang botol plastik masih sangat sedikit sekali. Hal ini terlihat dari jawaban kuisioner peserta, hanya 15\% dari 20 peserta yang telah melakukan daur ulang botol plastik (Gambar $4 \mathrm{~A}$ ). Persentase peserta yang mengetahui atau pernah mendengar mengenai bercocok tanam dengan metode hidroponik menggunakan botol bekas hanya 40\% (Gambar 4B). Namun, walaupun mengetahui pemanfaatan botol plastik untuk bercocok tanam hidroponik tidak ada yang melakukannya di rumah. Selain peningkatan pengetahuan peserta mengenai pemanfaatan sampah botol plastik, kegiatan ini juga terbukti berhasil meningkatkan minat peserta untuk memanfaatkan botol plastik bekas untuk bercocok tanam di rumah. Hal ini terlihat dari jawaban kuisioner peserta (Gambar 4C). Peserta pelatihan juga sepakat bahwa apa yang dijelaskan dan dipraktekan sangat mudah diterapkan di rumah masing-masing dan bahanbahan yang digunakan banyak tersedia di lingkungan tempat tinggal mitra.

A

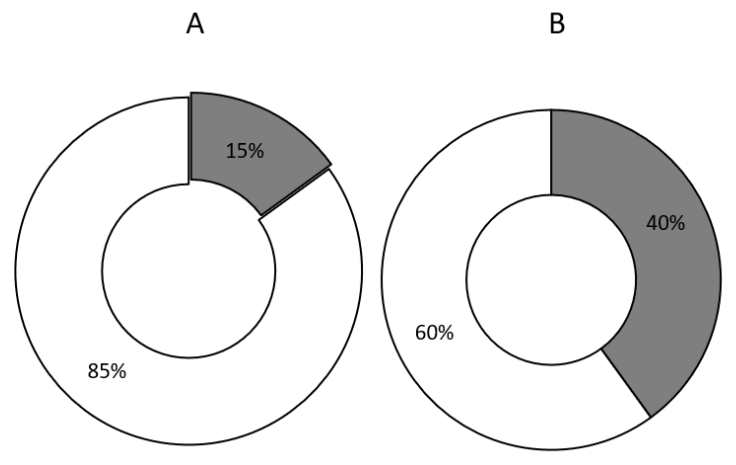

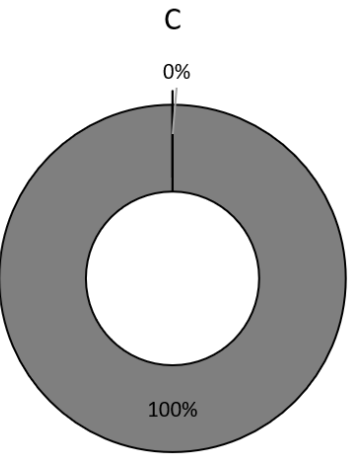

口Ya QTidak

Gambar 4. Pengetahuan peserta mengenai daur ulang botol plastik. A. Persentase peserta yang telah melakukan daur ulang botol plastik; B. Persentase peserta yang mengetahui mengenai bercocok tanam dengan metode hidroponik menggunakan botol bekas; $C$. Persentase minat peserta setelah pelatihan akan bercocok tanam secara hidroponik dengan memanfaatkan botol bekas di rumah

Pelatihan mengenai bercocok tanam dengan sistem hidroponik berbasis ramah lingkungan melalui pemanfaatan sampah botol plastik dirasa sangat bermanfaat sekali oleh para peserta. Terlihat dari jawaban kuisioner yang diberikan dimana seluruh peserta menjawab setuju (Gambar 5). Kegiatan ini selain bertujuan untuk mengatasi masalah limbah botol plastik juga diharapkan mampu mendorong kemandirian ekonomi peserta melalui pemanfaatan sampah botol plastik. Lima belas peserta dari 20 peserta setuju bila hasil penanaman sayur hidroponik dengan botol bekas di rumah dapat mengurangi biaya belanja sehari-hari terutama sayur-sayuran (Gambar 5). 

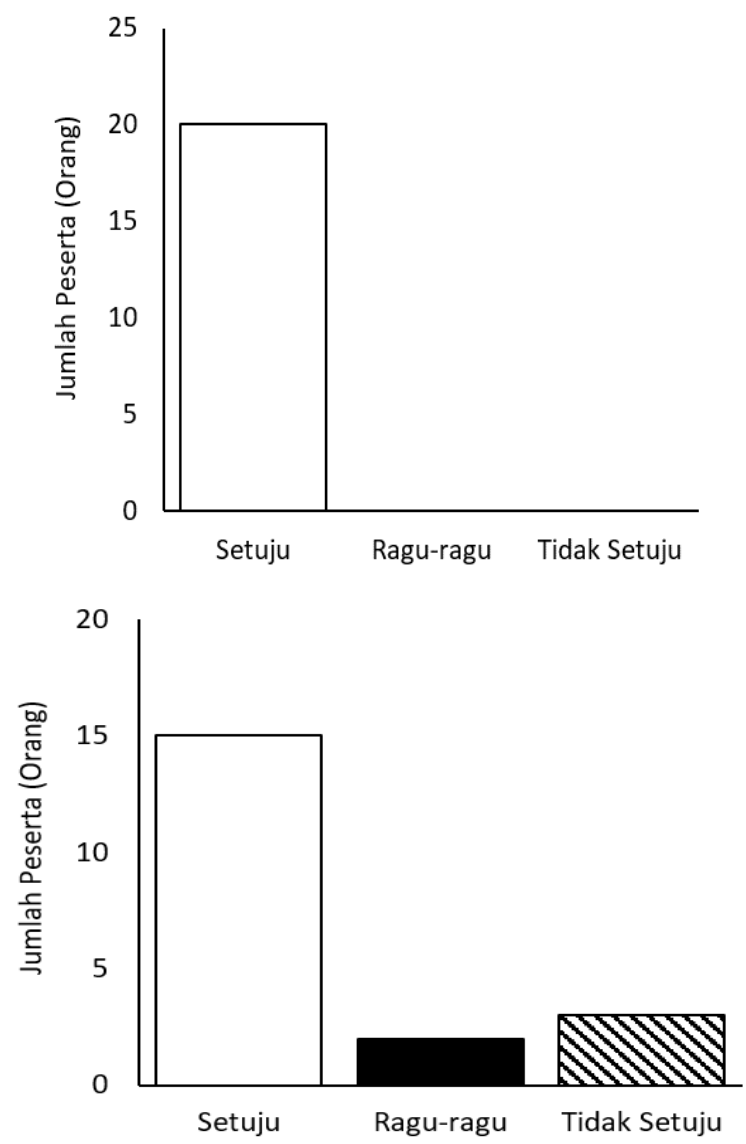

Gambar 5. Respon peserta terhadap kebermanfaatan kegiatan (kiri) dan pandangan peserta bila tanaman sayur hasil hidroponik dengan memanfaatkan botol bekas di rumah dapat mengurangi biaya belanja sayuran rumah tangga (kanan)

\section{SIMPULAN}

Hasil kegiatan penyuluhan dan pelatihan bercocok tanam dengan sistem hidroponik berbasis ramah lingkungan melalui pemanfaatan sampah botol plastik yang dilakukan bersama ibu-ibu PKK Karang Anyar RT 014/RW 001 Kelurahan Karang Anyar, Jakarta Pusat berhasil meningkatkan pengetahuan dan minat mitra untuk memanfaatkan sampah botol plastik sebagai media bercocok tanam hidroponik. Kegiatan ini merupakan terobosan baru dalam mengurangi masalah plastik yang ramah lingkungan. Selain itu, kegiatan ini dapat mendorong kemandirian ekonomi mitra dengan mengurangi biaya belanja sayuran rumah tangga sehari-hari. Mitra memberikan respon yang sangat positif terhadap kegiatan yang telah dilakukan dan menilai kegiatan ini sangat bermanfaat. 
Jurnal Pelayanan dan Pengabdian Masyarakat (PAMAS)

\section{DAFTAR PUSTAKA}

Asker, H. M. 2015. Hydroponic technology for lily flowers and bulbs production using rainwater and some common nutrient solutions. African Journal of Biotechnology. 4 (29): 2307-2313.

Azad, A.K., I. Katsumi., J. C. Diaz-Perez., T. E. El-Jaoual. and N. Takeda. 2013. Growth and development of komatsuna (Brassica rapa L. Nothovar) in NFT (nutrient film technique) system, as influenced by natural mineral. Agricultural Sciences. 4(7A): 1-7.

Babu, A. V, I. Antony. and E. V. Ramasamy. 2014. Removal of Cadmium from water with Nutrient Film Technique (NFT). LAKE: Conference on Conservation and Sustainable Management of Wetland Ecosystem in Western Ghats. $13^{\text {th }}-15^{\text {th }}$ November: $152-156$.

Barbosa, G. L., F. G. A. Gadelha., N. Kublik., A. Proctor., L. Reichelm., E. Weissinger., G. M. Wohlleb. and R. U. Halden. 2015. Comparison of land, water, and energy requirements of lettuce grown using hydroponic vs. conventional agricultural methods. Int. J. Environ. Res. Public Health. 12: 6879-6891.

Jenkins, G., Keeffe. and N. Hall. 2015. Planning urban food production into today's cities 35-47. Future of Food: Journal on Food, Agriculture and Society. 3 (1): 35-47.

[KLHK] Kementerian Lingkungan Hidup dan Kehutanan. 2018. Sistem Informasi Pengolahan Sampah Nasional (SIPSN). Komposisi Sampah. http://sipsn.menlhk.go.id/?q=3akomposisi-sampah. Diakses tanggal 20 Agustus 2019.

Lingga, P. 2011. Hidroponik Bercocok Tanam Tanpa Tanah. Cetakan XXXII. Penerbit Penebar Swadaya. Jakarta.

Mohammed, S. B., and R. Sookoo. 2016. Nutrient film technique for commercial production. Agricultural Science Research Journal. 6 (11): $269-274$.

Pratiwi, P. R., M. Subandi. and E. Mustari. 2015. Pengaruh tingkat EC (electrical conductivity) terhadap pertumbuhan tanaman sawi (Brassica juncea L.) pada sistem instalasi aeroponik vertikal. Jurnal Agro. 2(1): 35-42.

Rababah, A. 2017. Hydroponics removal of wastewater's contaminants for the generation of commercially valuable plants and environmentally sound effluent for the dead sea communities. Jordan Journal of Civil Engineering. 1 (3): 273 -286.

Roidah, I. S. 2014. Pemanfaatan lahan dengan menggunakan sistem hidroponik. Jurnal Universitas Tulungagung BONOROWO. 1(2): 43-50.

Romadloni, P. L. 2015. Rancang bangun sistem otomasi hidroponik NFT (Nutrient Film Technique). e-Proceeding of Applied Science. 1 (1): 75-84. 
Sardare, M. D., and S. V. Admane. 2013. A review on plant without soil - hydroponics. IJRET. 2(3): 299-304.

Sesanti, R. N., dan Sismanto. 2014. Pertumbuhan dan hasil pakchoi (Brasicca rapa I.) pada dua sistem hidroponik dan empat jenis nutrisi. Jurnal Kelitbangan. 4(1): 1-9.

Surtinah. 2016. Penambahan oksigen pada media tanam hidroponik terhadap pertumbuhan pakcoy (Brassica rapa). Jurnal Bibiet. 1(1): 27-35.

Wachjar, A., dan R. Anggayuhlin. 2013. Peningkatan produktivitas dan efisiensi konsumsi air tanaman bayam (Amaranthus tricolor L.) pada teknik hidroponik melalui pengaturan populasi tanaman. Bul. Agrohorti. 1 (1): 127-134.

Wibowo, S., dan S. Asriyanti. 2013. Aplikasi hidroponik NFT pada budidaya pakcoy (Brassica rapa chinensis). Jurnal Penelitian Pertanian Terapan. 3 (3): 159-167. 